\title{
REPORT OF THE TREASURER
}

The Treasurer this year again presents to the membership an abridged statement of the Society's financial position, set up in semiinformal narrative style. A copy of the complete Treasurer's Report as submitted to the Trustees and the Council will be sent to any member requesting it $f_{1}$ om the Treasurer through the Providence office. Moreover, the Treasurer will be happy to answer any questions members may wish to put to him concerning the Society financial affairs.

Returns on invested funds this year have been at the rate of $3.75 \%$ computed on book value after deduction of custodial expense. This is slightly less than last year.

\section{I}

\section{A Description of the Financial Position of the} Society as of May 31, 1966

The Society had Cash on deposit

In the Rhode Island Hospital Trust Company... \$202,092.35

In petty cash and drawing accounts......... $2,614.00$

It had Certificates of Deposit.

$\$ 204,706.35$ $300,000.00$

There was owing to it

By the United States Government

By members, subscribers and others (less allowance

for doubtful accounts)............. 211,323.43

It had prepaid expenses and deposits................. And it had invested in its Headquarters Building and

Office Equipment.

$\$ 19,865.25$

Making a total of Current and Fixed Assets of.

The Society also held Investment Securities valued at. . .............

(The approximate market value May 31,1966 was

$\$ 1,298,500.00$ )

Total Assets, therefore, were.

$\$ 2,006,383.96$

Offsetting these assets, the Society

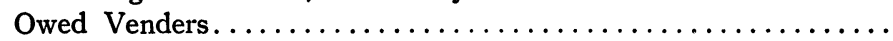

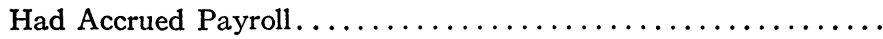

Had deferred payments of publication charges...............

Had reserved royalties payable to Russian authors............

Had deposits for Moscow charter flight...................

Had other miscellaneous liabilities and deferred in-

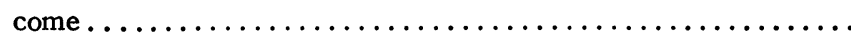

Had reserved in its Building Fund .....................

$\$ 122,201.45$

$\$ 879,781.56$

$1,126,602.40$

$\$ \quad 92,654.48$

$2,346.90$

$7,306.67$

$25,667.35$

$98,635.64$

$10,027.32$

$340,837.18$ 
Had funds and grants received from various special sources to support particular projects such as the Summer Institute, Symposia, etc.............

Had a surplus balance in its Publication Funds....

$\$ 178,284.75$

$105,019.20$

$\$ 283,303.95$

Less the amounts included therein representing $\mathrm{Na}$ tional Science Foundation grant balances unpaid.

$177,989.95$

$\$ 105,314.00$

$196,992.02$

And held in its General Fund the sum of $\ldots \ldots \ldots \ldots \ldots \ldots \ldots$

Thus accounting for all the Current Funds............. \$ $879,781.56$

The Invested Funds represent the following:

1. The Endowment Fund, largely the gift of members about forty years ago...............

2. Robert Henderson Endowment Fund.........

3. The Library Proceeds Fund, derived from the sale of the Society's Library in $1950 \ldots \ldots \ldots$. .

4. The Prize Funds-Bocher, Cole, Moore and

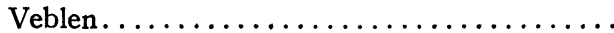

$\$ 100,000.00$

$547,223.20$

$66,000.00$

$8,575.00$

$50,245.39$

$80,000.00$

$243,007.34$

$31,551.47$

5. Dues and Publication Reserve Fund.........

6. Mathematical Reviews Subscription Reserve Fund.

7. Reserves established by the Trustees to protect life memberships formerly available, and as a "hedge" against investment losses...........

8. Other funds, derived mainly from bequests to the Society by members, which the Trustees were either required to invest or which they have invested at their option - the income being used for the general purposes of the Society...

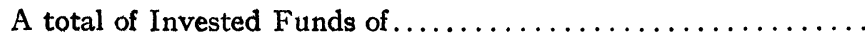
$\$ 2,006,383.96$

Total Liabilities and Fund Reserves, therefore, were

\section{II}

\section{An Account of the Financial Transactions of the Society DURING THE FisCaL YeAR 1965-1966}

The Society has two types of receipts: Funds for special purposes and projects, and the General Fund, from which are met the general operating expenses of the organization, including the publication of the Bulletin, the Proceedings, the Notices, and the Transactions. Income from sales of and subscriptions to these journals is placed in the General Fund, but in practice is allocated to the expense of the journals themselves. It is so treated in the following presentation:

To meet its General obligations, the Society Received:

From dues and contributions of individual members

From dues of institutional members......... $\quad 59,225.00$

From dues of corporate and associate members... $\quad 18,630.00$ 
Less: Amount allocated to Notices and Bulletin at members' subscription price.

From sales and support of scientific journals of the

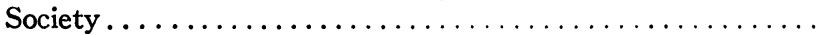

From investment and trusts. ...................

From publication charges. ...................

From miscellaneous sources....................

Transfers from other funds..................

Total General Receipts......................... $\$ 1,048,801.46$

These Funds were Expended:

For expenses of scientific journals of the Society.. $\$ 783,114.48$

For Organizational Expenses and Membership

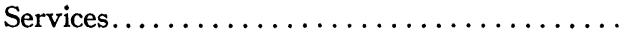

For Unrecoverable Overhead on grants and contracts........................... $\quad 8,689.50$

In Subsidies to non-Society publications........ $9,468.91$

For miscellaneous other expenses and Fund transfers.

$31,265.86$

For support of Mathematical Reviews....... 38,262.90

Total General Expenses.

$923,375.22$

Leaving an Excess of Income over Expenses of

$790,401.79$

$40,008.44$

$59,803.32$

$2,681.54$

272.89

Transferred to Building Fund...

$125,426.24$

$100,000.00$

Balance added to the General Fund.

$25,426.24$

Summary of Scientific Journal Accounts

\begin{tabular}{|c|c|c|c|}
\hline & Income & Expenses & $\begin{array}{r}\text { (Deficit) } \\
\$ 4,773.38\end{array}$ \\
\hline Bulletin & $\$ 78,746.29$ & $\$ 73,972.91$ & $\$ 4,773.38$ \\
\hline Proceedings. & $53,264.89$ & $85,482.04$ & $(32,217.15)$ \\
\hline Notices. & $101,093.63$ & $64,441.66$ & $36,651.97$ \\
\hline Transactions......... & $105,556.76$ & $100,324.72$ & $5,232.04$ \\
\hline Mathematical Reviews..... & $410,423.96$ & $411,970.45$ & $(1,546.49)$ \\
\hline athematics of Computation........ & $41,316.26$ & $46,922.70$ & $(5,606.44)$ \\
\hline$T$ & $\$ 790,401.79$ & $\$ 783,114.48$ & $\$ 7,287.31$ \\
\hline
\end{tabular}

Detail of Subsidies to Other Journals

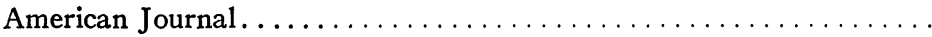

$\$ 3,068.91$

Canadian Journal . . . . . . . . . . . . . . . . . . . . . . . . . . 1,300.00

Pacific Journal. . . . . . . . . . . . . . . . . . . . . . . . . . . $2,700.00$

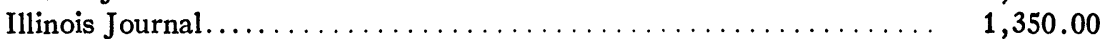

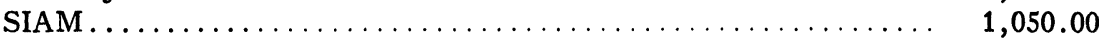

Total............................... $\$ 9,468.91$ 